\title{
The London library: an interview with Dunia Garcia-Ontiveros and Gill Turner.
}

Terezinha de Fátima Carvalho de Souza

\begin{abstract}
Doutora e mestre em Ciência da Informação pela UFMG. Professora Adjunta da Escola de Ciência da Informação da UFMG. Editora das revistas Perspectivas em Ciência da Informação e Múltiplos Olhares em Ciência da Informação.Editor de Perspectivas em Ciência da Informação
\end{abstract}

http://dx.doi.org/10.1590/1981-5344/3207

On February $17^{\text {th }}, 2017$ I had the opportunity to visit The London Library with my friend Judith Hodgson, an English specialist on rare books and a habitual user of this library. I would like to thank her and also thank the librarians Dunia Garcia - Ontiveros, Head of Bibliographic Services and Gill Turner, Head of Acquisitions.

The London Library1 was established on 1841 by Thomas Carlyle, and it had as members, authors like Charles Dickens, George Eliot, Virginia Woolf and T.S. Eliot. This last one was its president from 1952 to 1965. The Library's collection stands at over 1,000,000 volumes, covering over 2.000 subjects in 55 different languages which include works from the 16th century to latest publications. The Library is maintained by its members through their subscription.

Editor: Thank you for having me. When I told Judith I intended to come here I was longing to learn about you and how you conduct a library so different from the ones in our country! We don't have this kind of library in Brazil, it's always public or private, not a subscription one like yours, so I think the way you work it's a bit different from ours. I wonder if sometimes it's more complicated or maybe not ... I don't know the difference. But one thing I think it's important to understand is how you conduct your library and how you attend to your readers' necessities, and the different ways they learn about the organization of the collection, and about the selection of the books. I think it's very interesting to learn about how you select and preserve the books, therefore I would like to hear a little about how you do this.

\footnotetext{
14 St James's Square

London SW1Y 4LG

https://www.londonlibrary.co.uk/
} 
Gill: As far as libraries go I suspect we operate on a very similar basis to most other libraries, people come and borrow books and people bring books back, we buy books, we catalogue them and put them on the shelves. What makes us different is that as a subscription library we have no funding from the government, there's no funding from anything to do with academia, it's all money raised through the membership subscriptions, and any fundraising that we can do, as we have a team of people who raise funds for the library through events and other things, so this means that we are independent. We are not responsible to anybody except than our own board of trustees, which is great, but it does mean that we can't call on anyone else for help should we need it. So - pros and cons.

Editor: And you have to ask people to come and to make a lot of publicity, I mean, how do you keep up the numbers of the readers?

Gill: Well, there are a lot of readers who have always known about the library and there is a certain degree - a lesser degree - of families who have always belonged, so that the generations feed through who can't imagine life without the London Library. Some of them may have taken out a life subscription when they were 21 which was sort of a traditional thing to do fifty years ago maybe, not quite as much now tastes change. But there is also a lot of word of mouth, people who know someone else who belongs, or members who belong are advocating our benefits to their friends and colleagues. There's quite a lot that way. We advertise a little bit at certain times of the year or there may be an event on, people probably searching for libraries that they can get access to, that they cannot get into other academic libraries because they don't belong or they are not an alumnus of the library, and similarly public libraries don't offer the breadth and depth of the collections that we offer. So we fill a need somewhere in the middle there for perhaps people who are perhaps not studying in academia but who want more resources than the public library for their researches, so there will be many journalists and writers, a certain number of corporate members as well, art galleries and people like that, who need the sort of services we can offer.

\section{Editor: Is it a more general collection?}

Dunia: It's arts and humanities, it's not a technical library. It never tried to be, it never tried to compete with technical libraries. But I think getting the word out there and recruiting members is one of the eternal challenges of the London Library. We are still surprised at how many people have never heard of the London Library, and we actually within our Development Team have a specialist in marketing and we have a specialist in communications and their job is basically to publicise and to raise the profile, whether it's through newspapers, magazines and 
occasionally on the television, certainly on the internet, social media, so we are constantly trying to reach as many people as possible, to try to convince them that this is a worthy investment.

Judith: But you don't let absolutely anybody in because you do have to behave yourself here.

Dunia: Well you do, but I think this is one of the images that we have that we would rather not have, because we are trying to be as inclusive as possible but we have somehow acquired a bit of an elitist reputation. We want civilized people but that doesn't mean that we are elitist. We obviously want people to behave in a civilized manner and I think the vast majority of our members do. I think anyone who is inclined to pay around $£ 500$ a year in order to use a library is a civilized human being already, I don't think that is a problem. But it's trying to reach as many people as possible, and once we have reached them and persuaded them to join it's trying to make sure that we retain them, because some people only join for a short period of time if they are working of a project and they need access to the collection. When the project is over they might not stay on, and in fact we find that the greatest churn, if you like, of members happens after the first year or two years, so that's another challenge that we have: once we have got them here, to make sure that we understand the needs that you mentioned before and we meet those needs. A part of it is making sure that they know everything that comes with their membership. We invest a lot of money in electronic resources and we suspect those are still under-used and we think that if members truly understood what their membership offers and made the most of it, they would be less likely to leave. It's a constant challenge.

Judith: Do you still have a day membership for $£ 10$ ?

Dunia: I don't think it's $£ 10$ but we do have temporary passes, weekly and daily, but it's on a last resort basis.

Editor: The subscription is for one day, one month, one year ... How do you renew it?

Dunia: The subscription is either life membership or annual membership which - I don't know about life membership - certainly the annual membership can be paid in monthly instalments, but that's not to say that people who take on annual membership stay for a full year. Sometimes after six months they disappear, only the payment stops.

Editor: They just disappear? You don't have an agreement?

Dunia: We do have an agreement but it's hard to enforce it. 
Gill: It's hard to enforce it, if somebody's paying through a monthly direct debit system because it's cheaper for financial reasons to do it that way. Many people prefer to pay that way. If they decide after six months that they have had the use that they want, there's nothing we can do to stop them cancelling their payment at the bank, and we're left thinking, where's the money? - and you can take it up legally and pursue it but on the whole it's not worth it. But if we can make the best service available to members on the whole they will want to stay because we are too good an offer to refuse, but a lot of people don't want to pay.

Editor: So, is it difficult to renew the collection? How many times do you do this during the year, every month, or do you have a time in the year when you buy new books?

Dunia: This is Gill's area.

Gill: Well, we buy them all the time, we're spending all the time. My job is to buy new books for the Library, along with the Librarian, she also selects books, but we spend all our time selecting books, and accepting donations, as a lot of books are offered through donation by members, both new books or second hand books, when they are what we call downsizing - when they are moving from a larger house to a smaller house, and they want to reduce everything including their book collections. A lot of people will offer them to us and say "do you want some or all of my books?" So I am always dealing with queries about possible donations to the library. But no, we buy books all the year round. There are two main seasons in the academic year, the January lists and the September lists, so we get bi-annual catalogues which I will look through and pick out material from, mostly academic publishers, but the Librarian then looks at what we call the trade publishers, people who are publishing the books which you will see in bookshops all the time, the biographies, the histories, the fiction that everybody wants to read. They get reviewed in the national week-end papers, and the Librarian will make a selection from those every week, as well as from one or two of the other literary review papers. So that's what members are reading about all the time, and then I'm buying the books, the sort of academic ones they probably won't read about, but they will find them on our shelves. They may see them referenced in the next few years - they get cited in other works - and that's the sort of material that I am looking for.

Editor: Is this selection based on the statistical work that you make on the use of the collection?

Gill: We don't study the usage of the collections in perhaps the way that we ought to, perhaps the way public libraries do, I don't know how other libraries do it, I've worked here for twenty years and I've lost track of what other people do. But we select books very much on the basis of 
what we have already got - does it fit the collection? - we will have a look and see if similar books are being used, but sometimes we will try a newish subject area, not something completely outlandish, but we will try something we think perhaps looks a little more interesting and that we haven't had before. But we are always looking to see what we previously had and has it been used, and deciding if we think yet another book on that subject is suitable, but it's based on who is the publisher, who's the author, how expensive is the book, all these things as well as is there any usage. Quite often there may not be any usage if there is a previous or similar title, but that does not mean that we won't buy it. It might mean that we need to have a few more titles in that area to attract a bit more interest for people who are searching on that subject.

\section{Editor: Nowadays, do publishers send you the books?}

Gill: Some do, some don't. In the past there were more, there were what we call gentleman publishers, individual people who owned publishing companies, and their names are still very common in British publishing, Jonathan Cape, John Murray, people like that, these are still publishers, there's nobody called like that anymore. But when they were around they were donating books to the library as a matter of course, and they were meeting librarians in the clubs around here, and it was all having a very lovely lunch here, have a copy of our book. But that's all long gone - long gone. But there are still, there's one of the major publishing groups which does donate its books to us, which is great, so that we can choose what we want and if we don't want it we can sell it ourselves, but we get quite a lot of new material that way. But some comes from members, of course, people writing books, the library is full of writers, a lot of them offer to donate their book if they can afford to.

\section{Judith: And do you have a suggestions book?}

Gill: A suggestions book; that's for members to suggest things that they think the library ought to have, but they don't necessarily want to be able to borrow themselves. They may have a copy or they may have seen one, and that's the book which is downstairs in the hall, and a lot of members like reading it to see what other members think, because it's not only suggesting book titles for us, it's also "can they complain" about something or suggesting that we ought to get more light bulbs for an area or whatever. It's just that they have the right to groan and grumble about everything. But there are book suggestions in there, so we look at them and we often say, yes, we already have this book, we look it up and tell them where the book should be - they don't actually think of looking at the catalogue - poor Dunia, working away. But we also have a scheme whereby members can make suggestions for books that they actually want to read. They come and ask at the desk, or email us or telephone us and say, "I'd like to see this book, are you going to get a 
copy, or have you thought of buying it?" It could be a brand new book, it could be an old book, sometimes one that we have previously had, but all those suggestions are seen by the Librarian and she decides whether or not she thinks it appropriate to add to the collection, and she agrees to 90 - 95\% of them, and occasionally I have to say to them, well, I'm sorry, either we can't get a copy or it's too expensive or doesn't fit the collection properly, it's often a bit too frivolous for us, it's something you could buy in a bookshop and read for yourself without any trouble. It's not something that we want to keep long term that's going to add value to the collection, because we are a serious collection.

\section{Editor: And do you have a problem of space?}

Gill: And we bind all our books, all our books are hardback books, we don't have paperback books, anything that we have to buy in paperback we will bind into hardbacks, and that adds extra costs to the book, so all these things have to be thought of all the time, when we are deciding whether or not we are going to get something. And if we are not, we have to say to the member why we are not, because if you don't tell them they come back and challenge you if they are not happy with the decision. In old days they didn't but in these days they do. Our members are nothing if not articulate.

Editor: What about periodicals, do you have a collection?

Dunia: Yes, we certainly have, and again, this is part of Gill's remit.

Gill: Yes, we take a lot of periodicals, somewhere in the region of 650 titles, many of them we still take as print copies, and then we bind them up into annual volumes, and we keep them on the shelves. But a lot we also take as an online resource and some titles we are now taking as an online only format as we've realized that there's not really the demand for reading some of the academic journals the moment they are published. People will read them online, they don't need to see the print copy, so there's no point in buying the print issue and then binding it and adding it to the shelves, so it's saving us money on the cost of buying it, the cost of binding it and the cost of the shelf space, bills over the years. Yes, we have a lot of journals we currently subscribe to. We also subscribe to a number of online archive packages as well, like JSTOR which is American, which has hundreds, if not thousands now, of titles that we subscribe to through this package, and it's archives of titles across all the subjects. We pick the humanities bundles, but they are very popular.

Editor: Is it an online collection? 
Gill: It's an online collection, it's the archives of all the various journal titles that are appropriate to our collection, some of which we would never subscribe to. There are many titles which I think members probably aren't interested in, but they come as a bundle - you get 100, 150,300 titles of which 150 may be really useful, and the other 150 may or may not be, but it comes as part of the package.

\section{Editor: And is it free for the use of the readers?}

Gill: Once the members have paid their subscription fee, then all these materials are free, it's part of what they are getting through their subscription, access to these items, for which they can go online on our website, they type in their membership number and their PIN number their pass number - and that will give them access to the journals, and without that they can't see them.

\section{Editor: How many librarians do you work with?}

\section{Dunia: How many staff we've got here? Is it around 60?}

Gill: It's between 50 and 60 full time and part time, of which 20 25, maybe, at the most, are qualified librarians, and the rest are either para-professionals so that they work at the front desk, they are not of the support team, or cleaners, or anything like that, it's other people who work in the library, with the books, and we have an acquisitions team, we have a bibliographical service unit who do the cataloguing, we have another team who are responsible for getting the books prepared for the open shelves, and do the shelving and the maintaining of the stock. They can look for damaged books. There's an IT department, a marketing department and a membership department, and there's the development team who look after all the fundraising, and we have someone who looks after the archive side of the library, although she isn't actually an archivist - I think she's called the heritage librarian, and she will do research on interesting topics about the library for the fund raising to be able to attract members, she will put blogs on the website and things like that.

Editor: What kind of organization do you use here for cataloguing, is it Dublin Core or MARC?

Dunia: It's MARC. We use Aleph, which is an Ex-Libris library management system, and we catalogue in MARC - still. Who knows how much longer MARC is going to be around for? But we recently switched from AACR2 to RDA. Up until January 2015 we used to catalogue according to Anglo-American Cataloguing Rules $2^{\text {nd }}$ edition, AACR2, but there is now this new standard, Resource, Description and Access. 
Editor: We call it RDA too.

Dunia: We decided to adopt RDA in January 2015, so it's been more than a year now, so everything new, now that we catalogue, we catalogue according to RDA, but we also have this large retrospective cataloguing project underway. Everything that we acquired before 1950 was catalogued in a printed catalogue and we are gradually transferring that to the online catalogue, and it's a huge project. We are talking about hundreds of thousands of bibliographic records, so it's taking a long, long time. them?

Editor: And you do have to put all of them, I mean, you can't move

Dunia: No, we're not doing a bulk digitalization of the printed catalogue, we are actually physically going to the stacks, finding the books that haven't been catalogued online, bringing them to our office and then cataloguing them book in hand. We use a lot of imported records that we downloaded years ago, but a lot of the time there isn't an imported record, so we still have to do original cataloguing. So it's very labour intensive and very time consuming.

Editor: What about the system, is it your own system or a commercial one?

Dunia: It's a commercial system, it's Aleph, it's by ExLibris, they're probably the biggest company there is at the moment, they develop Alma as well, which is quickly taking over now because Alma has been developed with linked data in mind and it's being adopted by more and more libraries all over the world.

\section{Editor: And the classification as well, is it Dewey classification?}

Dunia: No, it's London Library classification, it's completely unique to us and it was developed in the $19^{\text {th }}$ century. You could argue that it isn't a real classification, that it's just a shelf arrangement system, because it doesn't have a notation, no alpha numerical notation, like, say, Dewey or Library of Congress. Instead we just use text, you know, textual labels, so we have a section, for example a wonderful Science and Miscellaneous section. It's subdivided by several topics, random topics and they're just arranged in alphabetical order. So books on "dentistry" are close to books on the "devil," simply because they both begin with d.e., so it's not a very scientific arrangement but it is a very user-friendly and intuitive arrangement and the members like it.

Editor: And the members can go to the shelves, which I think it is an important thing to help the reader... 
Dunia: I think the thing that defines the London Library and the reason that it was founded in the first place is that it's a lending library, unlike the British Library, and $97 \%$ of our stock - I think that figure's correct - is on our open shelves, and the whole point is that members can browse, and can borrow the vast majority of what we have. Even the small number of books that we have to keep in the safes, because they are quite rare or valuable or fragile, many of those can be borrowed as well. Members just have to sign a form saying that they will take extra care of them. But we are all about lending, so providing access to the books, and making sure that they are arranged in a fairly intuitive and simple way is very important. him.

Editor: I think it's important to help the reader and not to confuse

Dunia: But it is challenging at the same time because it is a Victorian classification scheme and of course the collection that we get is a very modern collection, we are constantly acquiring new books, about very new realities and very modern perspectives on the world and sometimes trying to shoe-horn those into a classification scheme that was designed at the end of the $19^{\text {th }}$ century. It can be challenging, so occasionally we do change our own classification scheme, we have to keep updating it, but we have to do it in a very sympathetic way, because we don't want to lose the flavour of it, and we want to preserve the tradition that is embodied in that scheme.

Editor: So the new librarians don't like it and come up with some censorship?

Gill: Criticism, perhaps, criticism is best. People still want to work at the London Library. Within librarianship there is still, I think, a cachet, people want to come and work here, there is something about being able to say that you have worked at the London Library, that will probably be able to get you another job further down the line. It looks good on a curriculum vitae, so we will take young staff who will join us and they tend to stay. My colleague upstairs has been here for 43 years. Many librarians have been here for 30 years, 35 years. I've been here for 20 years. Once you find a job that suits you, and we are unique in how we do things in so many ways, you tend to want to stay. But for young people joining the Library, which is great that they want to come and work here, it can mean that there's nowhere to go because the rest of us are sitting very comfortably. There are no senior positions - we have no intentions of going anywhere, if we can help it. But it's great that people do want to join. We always get lots and lots of applications for the posts. 
Editor: And how about digitalization, do you think it's a problem for you and for the use of the library? How do you see the future, as a lot of people are saying that the libraries will close?

Gill: Digitalization - there are various strands to it, there's the question of, do you take on more online resources, rather than keep buying print resources. We are still doing both, we are very much a print library, but we understand the appeal of online materials, but at the same time we don't want to be necessarily duplicating everything online when we have it in print. And then there's the question of digitalizing your collections in the sense that, do you have materials that are perhaps very fragile and which would benefit from being converted into a digital format? There can be a lot of pressure from people to do that, as that seems to be a good idea, so why don't you do it? And you say, let me sit you down and tell you how this could work - if you have the money for it. There's a lot of cost involved, and how do you decide what you are going to digitalize? Certain books you think, yes, yes, we must do it, but there may not be actually any market for it, nobody actually wants to read it. Just because it's a fragile book doesn't mean that you have to digitalize it. Other people are suggesting that maybe you should open your library to perhaps photographic resources, people who could come and take pictures of all the lovely old prints that are in some of your books and they can sell them and make them available, and you and the library can benefit from the licensing of your picture collections in some way and the pictures in the text. A number of libraries do that. They have had firms come in and go through all the travel books and take pictures of all the illustrations and the maps and what have you, and those libraries will gain a little financial consideration every time the picture is used somewhere. But digitalizing the collections wholesale is not something that we are looking at. I think the area that tends to get most attention of that sort of treatment is perhaps people's archives. We are not yet considering doing that with our archives. I think that there is some interesting material there, but we are a library first and foremost, and the archives are about the library, they are not the library. Other places that have interesting archives, say perhaps like the clubs - we have the gentlemen's clubs here in London, very well known - people want to see the archives because they want to know who the members are, and what else might have been done, and the clubs can actually afford to have those records digitalized. We would have to raise money in order to digitalize, perhaps, some of our membership records. Or we have to raise money for buying books, and keeping the building going, and buying more journals and buying more online resources, so - it would be lovely to digitalize the archives but it isn't necessarily a priority for us, although it is certainly something we do need to keep thinking about, because one day it will happen. 
Editor: Is strong the movement for libraries works with virtual information in

Dunia: I think that particularly academic libraries are doing that, aren't they? They are getting rid of a lot of their print collections and they are opening up library spaces more for collaborative work so that, students, groups of students can talk and work together, but I don't think that that's the way forward for the London Library and I think our members love losing themselves in the shelves and using actual real books. But I think that also, yes, we do want to step up our digital offer, but I think that's always going to have to be alongside maintaining the physical collections and the physical spaces. I think our members love coming to work here. A lot of them are professional writers of one description or another. So having access to space in central London where they can work quietly surrounded by books that they can keep dipping into for their research and also, because I think writing is quite a solitary profession, a place where they can meet with fellow writers and feel that they are part of a community, is quite important and it's something that we try to foster.

Gill: We also have quite a lot of students because, as Dunia says, where their own university libraries are open and everything has gone, because everything has become an e-book - an electronic book - because they are opening up their spaces for collaborative working, and a lot of students are actually finding it very hard to work in that environment, and they come here because they want the peace and quiet that we can offer. You see students everywhere,

even in the silent reading room where they are not allowed to have laptops, they have to work just with the books and notepaper, there are still lots of young members using it and they said they want it because their own libraries are too noisy to work in.

\section{Editor: How many readers come here weekly or monthly?}

Dunia: We have about 6500 members. How many of them come to the Library regularly? I don't know - about a third of them, I would say.

Gill: Yes, about a third. Certainly more than the high hundreds, more like the low thousands. But it is hard to tell, some people come every day, without fail, they are queuing up at 9.30 to get in the door, just the same as you are trying to get them out at 8 o'clock at night, they spend all their time here, and there are others who may only come once a month if they are coming up to London for something else. Or they are having their books sent to them where they live because we offer what we call a country members' service, so that people who live in Scotland, France or wherever can have books sent to them. So they may never 
actually visit the Library at all. They find what they want in the catalogue, they contact us and we get the book off the shelf and we send it to them. They pay for it, it's all part of the membership subscription.

Editor: Is it open on Saturdays?

Gill: Yes, and they would like it open on Sundays.

Dunia: And without paying any more for their subscriptions.

Editor: In my university we have two libraries which stay open 24/ 7, but it's a great challenge, it's complicated to keep it that way.

Gill: The cost of it, I think, is what many members understandably don't understand. Because we are a private subscription library, they are paying for everything that we provide for them. So if they want a 24 hour service, if they want Sunday opening, they're going to have to increase their subscription, and they don't want to do that, they just think that somehow we have elastic purses - we can do that, then. There's no funding, there's no grants, there's no extra money coming from anywhere to afford all this. You can have 24 hour opening, but we will stop buying online journals, whichever you like.

Editor: Naturally you have a Council, a group of readers, who help you to define the policies of the Library, how does this work?

Gill: We have a Board of Trustees who are comprised of between 12 - 15 members, something like that, and there's a Chairman and a Secretary. It's part of how you have to be incorporated - I think is the word - because we are not a public limited company. We are a charity, therefore we must have a Board of Trustees with appropriate officials, and they are overall responsible for the running of the Library, but the day to day running of the Library is devolved on the Librarian, who in turn delegates it to her team of executive staff and then there are the heads of departments such as Dunia and myself, and there are the rest of the teams, as well, but the day to day running of the Library is done by the Librarian, and it's a huge job that she does.

Dunia: I think there's a constant dialogue between the members and the Librarian, particularly through the Suggestions Book. They are constantly telling us things that they like, things that they don't like, so I think that the Library is very responsive. We have to be responsive to what the members want and like, and we have also to be aware also of what's happening in other sectors, for example, of what's going on in academic libraries, what's going on in public libraries, the fact that some libraries are open $24 / 7$ because they are our rivals. They are the competition. So if we are trying to convince people that they should 
come and use us, instead of using their local public library, or if they are university graduates using, as alumnae, using their university library, why - if we want to persuade them to come and use us - we have to make sure that what we offer compares favourably with what other libraries are offering. So, yes, we can't be open $24 / 7$ but there are other things that we can offer that they won't find in other libraries, such as amazing print collections that other libraries have disposed of.

Gill: And a very personal service.

Dunia: Yes, and we are always available.

Editor: Judith loves this Library. (Laughter)

Dunia: A lot of people do, because we have considered, what if we extend our opening hours by introducing self-service, because then you don't have to pay to have as many staff in the library, and we think we could open longer, but we think that's just not the London Library way of doing thing, if you go down that route you lose that personal service that we're proud of, and we know our members appreciate.

Editor: That's all so very interesting! I think we stayed here much more than the 30 minutes we had agreed. Thank you indeed! 